\title{
Beyond Climate Risk: INTEGRATING SUSTAINABILITY INTO THE DUTIES OF THE CORPORATE BOARD
}

\section{BeATe SJAিFJeLL*}

Finding out how business can be a part of the shift to sustainability has never been more crucial. This article starts out by presenting the results of a multijurisdictional comparative analysis of corporate law, seeking to investigate the barriers, to and possibilities for, sustainable business in the dominant business form - the corporation. The social norm of shareholder primacy is identified as a major barrier to sustainability. Shareholder primacy has taken over the space that corporate law leaves open for the discretion of the individual corporate board.

The financial risks of ignoring the impacts of unsustainability have the potential to bring sustainability into the core of the profit-seeking purpose of the corporation. The article concludes with a brief presentation of a work-inprogress - a Sustainable Governance Model — which can be used as a starting point for businesses wishing to transition towards sustainability. The model can also form the basis of a corporate law reform proposal, which is arguably a necessary step to shift business away from the unsustainable 'business as usual' approach and onto a sustainable path.

\footnotetext{
* Professor Dr Juris at the University of Oslo, Faculty of Law, Department of Private Law; Professorial Research Fellow at Deakin University, School of Law (2016-2018); Project Coordinator of Sustainable Market Actors for Responsible Trade (SMART, 2016-2020) (smart.uio.no/), which is based at the University of Oslo. SMART has received funding from the European Union's Horizon 2020 Research and Innovation Programme under Grant Agreement No 693642, and I gratefully acknowledge its support. My warmest thanks to Professor Jean Jacques du Plessis, lead organiser of the seminar 'Investing in Sustainability' at Deakin Law School, Melbourne, in March 2018, and of the International Corporate Law and Governance Forum on Boards of Directors in Leeds in January 2018, as well as to Dr Jay Cullen, organiser of the Law, Finance and Sustainability conference in Sheffield in September 2017. Different segments of the research that this article draws on were presented at these three events, and I am grateful to the participants for inspiring discussions that have contributed to the development of the article, and to the wider SMART team for inspiring collaboration. The usual disclaimers apply. Further comments and feedback are appreciated. E-mail address: $<$ b.k.sjafjell@jus.uio.no>.
} 


\section{The Unsustainability of 'Business as Usual'}

We face a convergence of crises: environmental, social and economic. A fundamental shift from 'business as usual' and onto a path towards sustainability is necessary. Business and finance are significant drivers of the current state of unsustainability. At the same time - as is recognised notably in the UN Sustainable Development Goals ${ }^{1}$ - business and finance may be vital contributors to the achievement of global sustainability goals. ${ }^{2}$ Arguably, this contribution may be necessary to mitigate market and regulatory failure. A pervasive issue is how to realise the potential of corporate sustainability - of business and finance on aggregate contributing towards social and economic development within planetary boundaries.

This article focuses on the corporation, as the dominant form of doing business, and specifically on the role and duty of the corporate board. The impact of the corporation on society, and its potential for contributing to sustainability, is vital to our future and that of coming generations. The function of the corporate board is constrained through the social norm of shareholder primacy, with its narrow fixation on the short-term maximisation of returns for shareholders. Informed by a misleading dichotomy between economics and ethics, corporate boards face increasing conflict between their perceived duty to maximise returns for investors (falsely perceived as a legal duty) and society's expectations of corporate sustainability (often falsely perceived as being voluntary only). This is a systemically entrenched barrier to corporate sustainability.

The financial risks of ignoring the impacts of unsustainability may dismantle this misleading dichotomy. The financial consequences of climate change, and of pressure on other planetary boundaries, as well as of social inequality across

\footnotetext{
${ }^{1}$ United Nations General Assembly resolution 70/1, Transforming Our World: The 2030 Agenda for Sustainable Development, A/RES/70/1, (25 September 2015) <www.undocs.org/A/ RES/70/1>. More on the SDGs can be found here: <http://www.un.org/sustainable development/sustainable-development-goals/>.

${ }^{2}$ Ibid, and see, amongst many other examples, the outcome document of the United Nations Rio+20 conference in 2012, entitled 'The Future We Want', which: acknowledges that sustainability 'will depend on the active engagement of both the public and the private sectors'; supports 'regulatory and policy frameworks that enable business and industry to advance sustainable development initiatives'; and calls on the private sector to 'engage in responsible business practices': Resolution adopted by the General Assembly on 27 July 2012, A/RES/66/288 [46] <http://www.un.org/ga/search/view_doc.asp?symbol=A/RES/66/288\& Lang $=\mathrm{E}>$.
} 
and within countries, bring sustainability full circle into the core of profitseeking.

In Part II of this article, the grand challenge of our time is elaborated on, as a backdrop to the article's discussion of how to achieve sustainable business.

In Part III, the article draws on multijurisdictional, comparative analysis to explain the problematic nature of the social norm of shareholder primacy and its relationship to the corporate board's role and duty.

In Part IV, the article presents and discusses emerging literature on the financial risk of ignoring the impact of unsustainability, explaining how this financial risk brings sustainability into the core duty of the board.

Part V outlines two choices for corporate boards: they can either wake up to the financial risks of corporate unsustainability, or they can wait until liability for ignoring financial risks materialises and, through facing economic consequences, realise the inadequacy of 'business as usual'. Corporate boards wishing to go with the first choice will need a roadmap to do this, and the article concludes with a brief presentation of a tentative proposal for a way forward, which can also form the basis for corporate law reform. The latter is arguably necessary to achieve change quickly enough.

Part VI concludes with reflections on the hope for sustainable business.

\section{The Grand Challenge of Our Time}

The dire state of the world caused by the convergence of environmental crises is encapsulated in the concept of 'planetary boundaries' which was first identified in the ground-breaking article by Rockström et al in $2009,{ }^{3}$ and updated and re-affirmed by Steffen et al in 2015. ${ }^{4}$ Planetary boundaries express the ecological limits within which humanity can continue to develop and thrive for generations to come. The nine planetary boundaries identified so far define global sustainability criteria for critical environmental processes that regulate the stability of the life-support systems on Earth, securing the 'safe operating space' for humanity. ${ }^{5}$ According to Steffen et al, human production and

3 Johan Rockström et al, 'Planetary Boundaries: Exploring the Safe Operating Space for Humanity' (2009) 14(2) Ecology and Society 1.

${ }^{4}$ Will Steffen et al, 'Planetary Boundaries: Guiding Human Development on a Changing Planet' (2015) 347(6223) Science 736.

${ }^{5}$ See, eg, the UN General Assembly Secretary-General Synthesis Report 69/700, The Road to Dignity by 2030: Ending Poverty, Transforming All Lives and Protecting the Planet. Synthesis 
consumption are placing us at an increasing or high risk of overstepping at least four of the boundaries: climate change, biodiversity, ${ }^{6}$ land system change, and the biogeochemical cycles of phosphorus and nitrogen. ${ }^{7}$

The concept of planetary boundaries, which is used to denote the limits of our Earth system's tolerance to human-induced change, is the result of the work of an international multidisciplinary group of environmental scientists who, in 2009, pooled their knowledge of different Earth system processes to inform the world about the space for sustainable action within planetary boundaries. ${ }^{8}$ Their work reflects the growing scientific understanding that life and its physical environment co-evolve. This pioneering effort brought together evidence of rising and interconnected global risks in several different contexts where environmental processes are being changed by human activities. The planetary boundaries framework flags a set of issues critical to sustainability. It gives a dashboard of issues where our collective humanity is changing the fundamental dynamics of the Earth system most profoundly. ${ }^{9}$

The concept of planetary boundaries forms the framework within which new boundaries may be identified and better quantifications or metrics adopted. In line with this, the conceptual framework of planetary boundaries itself proposes a strongly precautionary approach, by 'setting the discrete boundary value at the lower and more conservative bound of the uncertainty range'. ${ }^{10}$ This work is a continuous natural-science work-in-progress, as scientists gradually

\footnotetext{
Report of the Secretary-General on the Post-2015 Sustainable Development Agenda, UN Doc A/69/700, (4 December 2014) 18 [75]: 'To respect our planetary boundaries we need to equitably address climate change, halt biodiversity loss' <www.undocs.org/A/69/700>.

${ }^{6}$ A quantitative global analysis of the extent to which the proposed planetary boundary has been crossed shows that, across 65 per cent of the terrestrial surface, land use and related pressures have caused biotic intactness to decline beyond 10 per cent - the proposed 'safe' planetary boundary. The authors state that biodiversity intactness within most biomes (especially grassland biomes), most biodiversity hotspots, and even some wilderness areas is inferred to be beyond the boundary, adding that 'such widespread transgression of safe limits suggests that biodiversity loss, if unchecked, will undermine efforts toward long-term sustainable development'; Tim Newbold et al, 'Has Land Use Pushed Terrestrial Biodiversity beyond the Planetary Boundary? A Global Assessment' (2016) 353(6296) Science 288.

${ }^{7}$ Steffen et al, above $\mathrm{n} 4$.

${ }^{8}$ Rockström et al, above n 3, and Steffen et al, above n 4. See, about the background, Sarah Cornell, 'Planetary Boundaries and Business: Putting the Operating into the Safe Operating Space for Humanity' (draft paper on file with current author).

${ }^{9}$ Cornell, above $\mathrm{n} 8$.

${ }^{10}$ Rockström et al, above n 3, Supplementary Information, Appendix 1, 7
} 
understand more of the complex interactions and feedback mechanisms in the global ecological systems. ${ }^{11}$

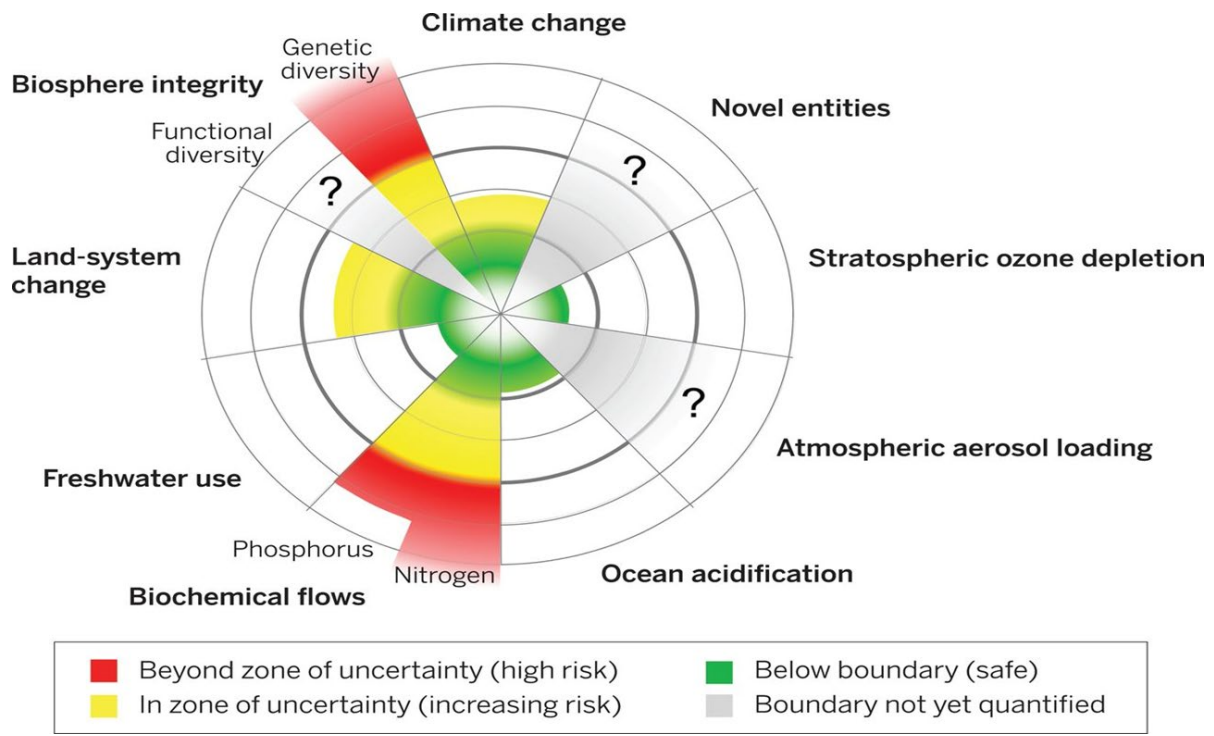

Figure 1: Planetary boundaries ${ }^{12}$

The concept of planetary boundaries or, in the terminology of the European Union, the 'limits of our planet', ${ }^{13}$ sets the outer framework within which the discussion of the contribution of business to sustainability should take place. Merely 'greener', or more environmentally-friendly, production is not sufficient. We must reduce the environmental impacts enough to stay within planetary boundaries. This also underlines the need for a life-cycle approach, encompassing all impacts of a product, from its design, to the sourcing of its materials, its production phase and transportation, its sale to the end-user, and its treatment (through recycling, upcycling, or waste management) after the end-user does not wish to use it anymore. This life-cycle approach is also sometimes denoted a 'cradle-to-cradle' approach. Similarly, the impacts of a service must be understood broadly in terms of its environmental and social

\footnotetext{
${ }^{11}$ See also Tiina Häyhä et al, 'From Planetary Boundaries to National Fair Shares of the Global Safe Operating Space - How Can the Scales Be Bridged?' (2016) 40 Global Environmental Change 60.

${ }^{12}$ The image is from Steffen et al, above n 4, and is reproduced with permission of its authors/ copyright owners.

${ }^{13}$ Decision No 1386/2013/EU of the European Parliament and of the Council of 20 November 2013 on a General Union Environment Action Programme to 2020 'Living Well, within the Limits of our Planet' [2013] OJ L 354/171, 176.
} 
effects. Such an approach contributes to transcending the fragmentation of responsibility for environmental impacts by corporation (or by country). ${ }^{14}$

Climate change and biodiversity are denoted as core boundaries, since transgressing either of them is enough to push the earth system out of its current stable state, which so far has constituted a relatively safe operating space for humanity. Researchers are still working to map and understand the complex interactions between planetary boundaries, including how changes in land use (for example to produce biofuel) can impact on both biodiversity and climate change. Humans have an enormous impact on earth biosystems,${ }^{15}$ but very little understanding of what havoc they are wreaking, or what the consequences will be. As this reality is gradually beginning to dawn on thought leaders in business and finance (albeit still very much limited to climate), they must attempt to understand these complexities in step with scientists, as the financial risks of unsustainability become ever clearer.

However, planetary boundaries constitute only the outer framework within which we must work to understand how to achieve sustainability, and the market actors' contribution to this. The grand challenge of sustainability lies in securing also the social foundation for humanity now and in the future while staying within planetary boundaries. Kate Raworth has been a driving force for the recognition of the significance of securing human rights and other fundamental social prerequisites to good lives, with the aim of achieving not just a safe but also a just operating space for humanity. ${ }^{16}$

\footnotetext{
${ }^{14}$ For a discussion of the difference between planetary boundaries that are truly global in the sense that only the overall magnitude of impact matters, and not the location, and those where the location of the changes matters, see Häyhä, above $\mathrm{n} 11$.

${ }^{15}$ Yinon M Bar-On, Rob Phillips and Ron Milo, 'The Biomass Distribution on Earth' (2018) 115(25) Proceedings of the National Academy of Sciences of the United States of America 6506.

${ }^{16}$ Kate Raworth, Doughnut Economics: Seven Ways to Think like a 21st-Century Economist (Chelsea Green Publishing, 2017).
} 


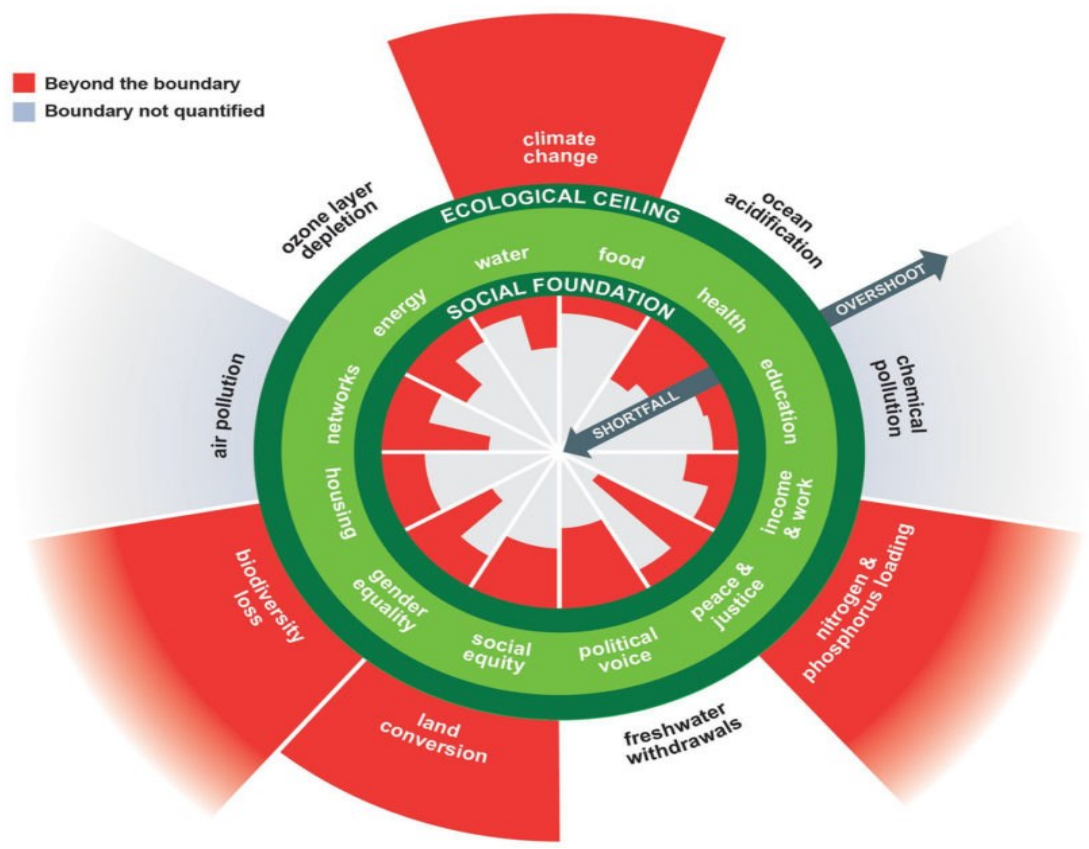

Figure 2: The social foundation within the ecological ceiling of planetary boundaries ${ }^{17}$

Raworth's starting point was the social goals submitted by member countries in the process of drafting the United Nations' Sustainable Development Goals (SDGs), and she selected the eleven social goals for which there was the greatest consensus. Since the SDGs were adopted, Raworth has updated her model, including peace and justice amongst the goals, so that it now encompasses twelve basic social goals which promote the protection of human rights and decent and good living standards. The goals may be seen as a global master plan to abolish poverty, mitigate inequality and stop climate change by $2030 .{ }^{18}$ They include: peace and justice; the abolition of poverty and hunger; the mitigation of inequality; the promotion of good health and education; gender equality; clean water and good sanitary conditions; clean energy; decent work and economic growth, innovation and infrastructure; sustainable cities and societies; responsible consumption and production; the mitigation of

\footnotetext{
${ }^{17}$ The figure is from Kate Raworth, 'A Doughnut for the Anthropocene: Humanity's Compass in the 21st Century' (2017) Lancet 1(2) <https://doi.org/10.1016/S2542-5196(17)30028-1>, and is reproduced in accordance with the Creative Commons user licence $<\mathrm{https} / /$ creative commons.org/licenses/by/4.0/>.

${ }^{18}$ See The Global Goals for Sustainable Development, The 17 Goals $<$ https://www.globalgoals. org/>.
} 
climate change; the protection of life on land and in water, and collaboration to achieve these goals. ${ }^{19}$ These goals encompass protection of both traditional and more recently recognised human rights as well as broader aspirational goals of the global society. The SDGS were adopted in 2015, together with the Addis Ababa Action Agenda on Financing for Development and the Paris Agreement for mitigating climate change, ${ }^{20}$ and provide a good basis for higher expectations of states and the private sector alike.

The research on planetary boundaries and the social foundations has been summarised by Melissa Leach, together with Raworth and Rockström. ${ }^{21}$ With the adoption of the SDGs, which has given a new impetus to the debate on how to achieve sustainability, the dual concept of planetary boundaries and the social foundation increasingly inspires sustainability discussions around the globe.

\section{How Shareholder Primacy Limits the Corporate BOARD'S FUNCTION}

In spite of much sustainability talk by business, ${ }^{22}$ we are still on an unsustainable track of 'business as usual'. One of the reasons for this unsustainable state has been investigated by a multijurisdictional comparative research project, the Sustainable Companies Project (2010-2014). The project has sought to identify the barriers to, and possibilities for, a deeper integration of environmental concerns into the decision-making in companies. ${ }^{23}$ The Sustainable Companies Project chose to focus on environmental sustainability,

\footnotetext{
${ }^{19}$ Already the inclusion of economic growth for all countries as a part of the SDGs indicates the lack of a coherent analytical and research-based approach to what sustainability means. See Beate Sjåfjell, 'Redefining the Corporation for a Sustainable New Economy' (2018) 45(1) Journal of Law and Society 29, passim.

${ }^{20}$ United Nations, Department of Economic and Social Affairs, Addis Ababa Action Agenda of the Third International Conference on Financing for Development (Addis Ababa, Ethiopia, 1316 July 2015) (see <http://www.un.org/esa/ffd/publications/aaaa-outcome.html $>$ ). Regarding the Paris Agreement see <https://unfccc.int/process-and-meetings/the-paris-agreement/theparis-agreement>.

21 Melissa Leach, Kate Raworth and Johan Rockström, 'Between Social and Planetary Boundaries: Navigating Pathways in the Safe and Just Pathway for Humanity' World Social Science Report 2013: Changing Global Environments 84 (OECD, 2013).

${ }^{22}$ See, eg, the approach of the World Business Council for Sustainable Development $<$ wbcsd.org/Overview/Our-approach $>$, and the SDG Business Hub $<$ sdghub.com/>.

${ }^{23}$ The presentation of the results of the company law analysis of the Sustainable Companies Project here is based on Beate Sjåfjell et al, 'Shareholder Primacy: The Main Barrier to Sustainable Companies' in Beate Sjåfjell and Benjamin J Richardson (eds), Company Law and Sustainability: Legal Barriers and Opportunities (Cambridge University Press, 2015) 79.
} 
recognising that this might be the dimension of sustainability that was the least influential in corporate decision-making, while also being the necessary basis for sustainability as a whole.

The project investigated core company law through an extensive, comparative analysis of the purpose of the company as a matter of law, and the role and duties of the board as well as that of the general meeting. Because of the board's pivotal role, according to company law, in the strategy-setting and overarching monitoring of the management of the company, ${ }^{24}$ the research focused on the concept of the interests of the company in order to establish the scope of the board's duty and discretion in its supervision and management of the company. The regulation, or lack thereof, of corporate groups also formed part of this investigation. Accounting and auditing law was also investigated, using a similar comparative approach, allowing for an in-depth analysis of the area of law where broader societal interests, through so-called non-financial or Corporate Social Responsibility (CSR) reporting, have made inroads. While the focus of the Sustainable Companies Project was on environmental externalities, the results are to a great extent transferable to social externalities.

In core company law, the possibilities for a shift away from business as usual and onto a sustainable path are greater than one might perhaps have expected. While the mainstream corporate governance debate tends to regard maximisation of shareholder profit as the sole purpose of companies, this is, to a great extent, incorrect as a matter of law. ${ }^{25}$ This is especially clear if we consider society's purpose in creating the corporate form: the underlying rationale for facilitating the corporate form through legislation is that it is thought to be beneficial for society through its contribution to economic development. While company law in some jurisdictions adheres to shareholder value (the legal concept, which we distinguish from the social norm of shareholder primacy), no company law system insists on boards focusing only on returns for shareholders. ${ }^{26}$ All jurisdictions expect boards to ensure legal

\footnotetext{
${ }^{24}$ The 'board' is used in this chapter as a general term encompassing the German Aufsichtsrat, the British board of directors and the board as constituted in the Nordic countries. Trying to fit quite different systems, exemplified by the German two-tier variant and the one-tier system of the UK, into one picture of a board level and a management level requires some simplifications, as the German Aufsichtsrat and the UK board of directors are two quite different things, with the German Vorstand ('management board') having some similarities with the UK board that the Aufsichtsrat ('supervisory board') does not have, and vice versa.

${ }^{25}$ Sjåfjell et al, above, n 25.

${ }^{26}$ In some jurisdictions environmental sustainability has begun tentatively to make inroads into the explicit duties of the board. See, eg, A Johnston, 'Reforming English Company Law to Promote Sustainable Companies' (2014) 11(2) European Company Law 63; T E Lambooy,
} 
compliance. We see examples of shareholder-value jurisdictions, such as the UK, expressly stipulating that broader societal concerns should be taken into account. ${ }^{27}$ Generally, company law across jurisdictions also allows boards to integrate environmental externalities to a greater extent than legal compliance requires, at least as far as the business case argument allows - that is as far as the case can be made that this is profitable for the company in the long run. Within the current system, company law on a comparative basis provides, perhaps, surprising latitude to the board, and by extension the management, to shape business in a sustainable manner. ${ }^{28}$

However, boards generally do not choose environmentally friendly, low-carbon options within the realm of the business case, let alone challenge the outer boundaries of the scope to pursue profit in a sustainable manner by going beyond the business case. Instead, the functioning of the board is constrained by the overriding social norm of shareholder primacy, which, supported by management remuneration incentives and other drivers, dictates that board and senior managers are the 'agents' of the shareholders and should maximise returns to shareholders. This social norm, which is so pervasive that it has become a legal myth, ${ }^{29}$ leads to an extremely narrow, short-term, focus on maximisation of returns to shareholders.

The barrier to corporate sustainability posed by the shareholder primacy norm is exacerbated by the chasm between company law's approach to corporate groups and the dominance and practice of such groups. While companies are 'creatures of national law', ${ }^{30}$ corporate groups are transnational, making a holistic regulation of heterogeneous groups across national borders extremely difficult. The parent company's tight control of the group in practice is

Corporate Social Responsibility: Legal and Semi-Legal Frameworks Supporting CSR: Developments 2000-2010 and Case Studies (Kluwer, 2010).

${ }^{27}$ Charlotte Villiers, 'Sustainable Companies: Barriers and Possibilities in UK Company Law' (2015) 11(1) International and Comparative Corporate Law Journal 105.

${ }^{28}$ This is supported for the institutional investors by the report Resource Efficiency and Fiduciary Duties of Investors, Final Report, ENV.F.1/ETU/2014/0002, DG Environment, produced by Ernst \& Young Cleantech and Sustainability Services (France) on behalf of the European Commission (hereinafter EY Report).

${ }^{29}$ Along with that of shareholders owning companies, which, as a matter of company law, they clearly do not. For an eloquent dismantling of the myth, see Paddy Ireland, 'Company Law and the Myth of Shareholder Ownership' (1999) 62 Modern Law Review 32 and Lorraine Talbot, Critical Company Law (Routledge, $2^{\text {nd }}$ ed, 2015).

${ }^{30}$ As repeatedly emphasised by the Court of Justice of the European Union. See Daily Mail, Case 81/87 [1988] ECR 5483, 5511 [19]: 'companies are creatures of the law' and 'exist only by virtue of ... national legislation which determines their incorporation and functioning'; repeated inter alia in Überseering, Case C-208/00 [2002] ECR I-9943, I-9971 [81]. 
perversely matched by the limited legal possibilities for holding the parent company liable for subsidiaries' environmental and social transgressions.

Attempts at mitigating the negative impact of shareholder primacy by promoting alternative social norms have so far been insufficient. So-called nonfinancial reporting has become a regulatory tool of choice not only for the EU but also for national legislators world-wide, in a desire to influence companies and their investors to take corporate sustainability issues more into account. Inspired by ideas based on reflexive theory, ${ }^{31}$ the compromise solution between those wishing to regulate companies' environmental and social performance more strictly and those who do not, is to ask companies to report on what they are doing. ${ }^{32}$ In spite of good intentions and much hard work in this area, reporting requirements are strikingly ineffective in influencing companies and their investors. Much reporting is based on voluntary and discretionary measures, leading to risks of corporate capture, lack of comparability, lack of consistency and uncertainty in benchmarking. ${ }^{33}$ Notably, the new EU nonfinancial reporting requirements, while they may be perceived as an intermediate step towards the internalisation of social and environmental impacts, currently lack the scope and the necessary verification requirements to be a real game-changer. ${ }^{34}$

With the shareholder primacy drive thus left mainly unchecked, the resulting general practice of companies is detrimental to those currently affected by environmental degradation, violation of human rights and economic exploitation and to the possibility for future generations to fulfil their own needs. It is also damaging to the interests of companies and of those shareholders with more than a very short-term perspective on their investment, including institutional investors such as pension funds and sovereign wealth funds.

This is not to say that all shareholders desire this outcome. To the contrary, a rising number of investors today claim to have a broader and more long-term

\footnotetext{
${ }^{31}$ Reflexive theory in the context of sustainability reporting is the idea that decision-makers in companies having to report on the environmental and social impacts of the company will think more about these issues, with the result that they will change the sustainability performance of the company for the better.

${ }^{32}$ Charlotte Villiers and Jukka Mähönen, 'Accounting, Auditing and Reporting: Supporting or Obstructing the Sustainable Companies Objective?' in Sjåfjell and Richardson (eds), above n $23,175$.

${ }^{33}$ Ibid.

${ }^{34}$ Charlotte Villiers and Jukka Mähönen, 'Article 11: Integrated Reporting or Non-Financial Reporting?' in Beate Sjåfjell and Anja Wiesbrock, The Greening of European Business under EU Law: Taking Article 11 TFEU Seriously (Routledge, 2015) 274.
} 
focus; these include pension funds, which by definition have a very long-term perspective. However, what may be referred to as socially responsible investing is still a fringe movement, ${ }^{35}$ and institutional investors are generally caught up in a system where misguided efforts at promoting efficiency and maximising value have led to short-term return requirements that exacerbate the narrow, short-term effect of the shareholder primacy drive. ${ }^{36}$ While many institutional investors appear to recognise that they will in the long run see the detrimental effects of failing to properly consider broader issues, notably climate change, they are under increasing pressure to maximise returns for beneficiaries in a context of persistently low yields and interest rates.

This negative impact of shareholder primacy occurs partly within the scope of the law and partly as a result of violation of the law. The former, the negative impact that occurs within the scope of the law, is a result of the companies and the shareholders exploiting the scope the law gives them to maximise shortterm returns. They do so through an externalisation of environmental and social concerns, by using loopholes and grey areas and taking advantage of the lack of international regulation of business. The negative impact of violation of the law, on the other hand, is often missed in the CSR debate, which speaks about what business and finance should do beyond the law, presupposing legal compliance that is not always present. Talking about what business and investors should do beyond the law serves to deflect attention away from the lack of legal compliance. It may also serve to explain the widespread faith in more reporting requirements as a mechanism to counteract shareholder primacy, rather than starting with proper supervision and enforcement of the rules and standards that are already in place. It also reflects a persistent belief that markets will self-correct through pressure from investors and corrections to share prices where misconduct or failure to disclose material information occurs. $^{37}$

We see here the contours of a negative spiral: boards are under pressure to maximise short-term returns, and reliable and relevant reporting on environmental, social and governance issues is therefore not a priority. Investors, more or less seriously, declare an intention to invest in long-term sustainability but do not receive the information they need from corporations to

\footnotetext{
${ }^{35}$ Benjamin J Richardson, 'Financial Markets and Socially Responsible Investing' in Sjåfjell and Richardson (eds), above n 23, 226.

${ }^{36}$ In spite of, for example, the EY Report, above n 28, confirming that institutional investors are allowed to take broader societal concerns.

${ }^{37}$ Of course, there is not a sharp dichotomy between law and ethics, or between lawful and illegal activities - they are not separate issues but rather a sliding scale on the spectrum from clearly legal and legitimate to obviously illegal and illegitimate.
} 
make the right decisions, while their fund managers are under the same pressure as corporate boards to show short-term maximisation of returns.

\section{The FinANCIAL Risk of 'Business as USUAL'}

The current linguistic dichotomy between financial and 'non-financial', illustrated notably by the EU Non-Financial Reporting Directive of $2014,{ }^{38}$ is informed by, and serves to further entrench, the understanding that maximising profits (or, even more narrowly, returns for investors) requires an externalisation of environmental, social and governance issues. By defining these issues as non-financial, or as concerning 'non-shareholder' interests, ${ }^{39}$ or as 'ethical' rather than 'economic', the message is clearly that these are extraneous concerns. Such concerns may be included in the decision-making of the corporate board only to the extent that the corporation is forced to do so through legislation that is enforced or by the dictates of 'socially responsible' controlling investors. They may also be included if the corporation wishes to have an 'ethical' or CSR profile, but only to the extent that they do not have a negative impact on financial performance.

An emerging literature on the financial risk of ignoring the impact of unsustainability serves to dismantle this dichotomy and helps us see that sustainability has a place among the core duties of the board, even where those duties are understood quite narrowly as promoting or even - contrary to corporate law - maximising profit (or returns for investors).

The Australian lawyer Sarah Barker is a powerful advocate for bringing the financial risk of climate change into the boardroom. Barker emphasises that climate change — with the already inevitable consequences that we cannot avoid even if the global society were to quickly and efficiently meet the goal of the Paris Agreement - entails financial risk for corporations. Members of

\footnotetext{
${ }^{38}$ Directive 2014/95/EU of the European Parliament and of the Council of 22 October 2014 amending Directive 2013/34/EU as regards Disclosure of Non-Financial and Diversity Information by Certain Large Undertakings and Groups [2014] OJ L 330/1.

39 See Beate Sjåfjell, 'Redefining Agency Theory to Internalize Environmental Product Externalities. A Tentative Proposal Based on Life-Cycle Thinking' in Eléonore Maitre-Ekern, Carl Dalhammar and Hans Christian Bugge (eds), Preventing Environmental Damage from Products: An Analysis of the Policy and Regulatory Framework in Europe (Cambridge University Press, 2018) 101.
} 
corporate boards cannot fulfil their role if they reject or ignore the science of climate change. ${ }^{40}$

In 2017 the Cicero Centre for International Climate and Environmental Research in Oslo issued the report Shades of Climate Risk for investors, which is also directly relevant and applicable for corporate boards. ${ }^{41}$ The Report complements the recommendation of the Financial Stability Board's Task Force on Climate-Related Financial Disclosure, ${ }^{42}$ disclosing potential impacts of climate-related risks and opportunities, and giving guidance on scenarios for stress-testing. The Report discusses two groups of risks: physical risks and transition risks.

The physical risks are those that a changing climate entails, such as sudden and gradual changes to our natural environment, including warmer, wetter and wilder weather, floods and landslides, sea level rise, droughts and heat stress. Ignoring these predictions may lead corporate boards to make financially risky investments, for example in property that will not be possible to develop, or to fail to put in place necessary measures, for example the fortification of factories against the changing physical environment.

While much of the discussion focuses on climate change, a similar picture may be drawn for other environmental issues, for example other forms of pollution, loss of biodiversity, ocean acidification, deforestation and other land change, and pressure on fresh water (and these are complex, interconnected processes). The physical impacts of continued environmental degradation may have direct financial consequences for corporations in various sectors, and a corporate board lacking in awareness or knowledge about these issues may increase the financial risk for the corporation through the decisions it makes or fails to make.

There are (at least) two levels on which the physical risk of climate change and other environmental degradation represents financial risk for corporate boards. The first is on the level of the individual corporation which needs to anticipate and adapt to physical changes in the natural environment as far as possible. This may involve changes in insurance levels, in investments or in the very business model of the corporation. The second is on the aggregate level of the sector, in

${ }^{40}$ See, eg, Sarah Barker, 'Directors' Personal Liability for Corporate Inaction on Climate Change' (2015) 67(1) Governance Directions 21.

${ }^{41}$ Christa Clapp et al, Shades of Climate Risk. Categorizing Climate Risk for Investors (2017) $<$ http://hdl.handle.net/11250/2430660>.

42 Task Force on Climate-Related Financial Disclosures, Final Report: Recommendations of the Task Force on Climate-Related Financial Disclosures (June 2017) <https://www.fsbtcfd.org/publications/final-recommendations-report/>. 
a country, a region or globally. In addition to anticipating and adapting to environmental risks, a corporation or an aggregate of corporations may more actively mitigate climate change or other environmental degradation to ensure the continued viability of the corporation's business. For example, an agricultural sector dependent on bees, wasps and other pollinators, may collectively work to reduce the use of pesticides and mitigate other threats to pollinators. Not doing so, while continuing with the same line of business, involves the financial risk of reduced crops. Anticipating, adapting and, where possible, mitigating environmental change is therefore an intrinsic part of the corporate board's risk management in the core financial sense.

The transition risks described in the report Shades of Climate Risk include policy risks, liability risks and technology risks. Policy risks concern the 'risk' of changes in corporate policy to mitigate climate change, which will impact in varying degrees on different sectors and individual corporations. Anticipating and adapting to changes to the regulatory environment through policy-making is clearly also a part of the financial risk management of the corporation. Corporate boards taking the more cynical approach of betting against climate change mitigation by expecting no policy changes in that direction, may be making a correct judgment call in that respect. ${ }^{43}$ They will then, however, need to see this in connection with the financial risks of climate change itself, which will most likely be exacerbated if policy-makers do not regulate to mitigate. On the aggregate level of business lobbyism, a more active approach to policy risk - promoting policies that will mitigate the physical risk of climate change may accordingly be the best financial risk management. Such an active approach may also be beneficial in the sense that this may give the corporate decision-makers a higher degree of certainty about upcoming changes in laws and policies. Conversely, when corporations work against necessary policies, as is discussed by Cushman in relation to ExxonMobil ${ }^{44}$ the financial risk in the form of liability risks rises.

Liability risks may take the form of investors suing either corporations or the board members directly for loss of profit arising from failure to anticipate and adapt to climate change or other environmental degradation. Liability risks may also take the form of lawsuits brought against the corporation or the board members directly for damage caused to people or communities by the corporation's contribution to climate change or other environmental degradation. This also applies to harm caused by the corporation through

\footnotetext{
${ }^{43}$ The Report leaves this rather open.

${ }^{44}$ See John H Cushman, 'Harvard Study Finds Exxon Misled Public about Climate Change', Inside Climate News (online), 22 August $2017<\mathrm{https} / /$ insideclimatenews.org/news/ 22082017/study-confirms-exxon-misled-public-about-climate-change-authors-say>.
} 
violation of human rights or complicity in corruption - the social and broader governance dimensions of sustainability. ${ }^{45}$ While who would have standing to sue, and the likelihood of a lawsuit's success, would vary with the procedural rules across jurisdictions, such lawsuits would entail a varying degree of financial risk for the corporation. The risk would arise from the lawsuit itself - the costs associated with lawyer's fees, time spent, possible damages that have to be paid and negative reputational impacts - which may lead to lower profit caused by negative reactions from potential customers, contractual parties and investors.

The international increase in lawsuits against corporations, including parent corporations, for environmental or social harm allegedly caused by their subsidiaries, and against lead corporations for negative environmental or social impacts in their global value chains, shows that this risk is materialising. ${ }^{46}$ While many cases are rejected for procedural reasons, and many lost, some are won, and the sheer multitude of cases makes them a driver for change in themselves. They also underline the financial risk of ignoring sustainability. The financial risk of carrying on with mainstream governance models through corporate groups or global value chains is also illustrated through these cases. While corporate law may start from the supposition that a parent corporation is not responsible for its subsidiaries' actions, and even less so a lead corporation for that of its global value chains, modern financial risk management will increasingly need to take a broader - arguably a life-cycle-based - approach.

The third type of transition risk discussed in the Shades of Climate Risk report is that of technology changes. The risk of 'stranded assets' - assets that no longer have value - to any corporation involved in exploiting fossil fuels is the obvious example here. The shift from fossil fuels to renewables presents a great financial risk to corporations planning to profit in the long run from oil, gas or coal. ${ }^{47}$ However, this risk is also borne by corporations indirectly relying

${ }^{45}$ For a list of cases see 'Legal Case Map', Business and Human Rights Resource Centre, $<$ https://www.business-humanrights.org/en/corporate-legal-accountability $>$. See also Jennifer Zerk, Corporate Liability for Gross Human Rights Abuses - Towards a Fairer and More Effective System of Domestic Law Remedies. A Report Prepared for the Office of the UN High Commissioner for Human Rights (OHCHR, 2014) <https://www.ohchr.org/Documents/ Issues/Business/DomesticLawRemedies/StudyDomesticeLawRemedies.pdf $>$.

${ }^{46}$ See generally Michal Nachmany et al, Global Trends in Climate Change Legislation and Litigation: 2017 Update (Grantham Research Institute on Climate Change and the Environment, May 2017) <http://www.lse.ac.uk/GranthamInstitute/wp-content/uploads/2017/ 04/Global-trends-in-climate-change-legislation-and-litigation-WEB.pdf $>$.

${ }^{47}$ Beate Sjåfjell, Heidi Rapp Nilsen and Benjamin J Richardson, 'Investing in Sustainability or Feeding on Stranded Assets. The Norwegian Government Pension Fund Global' (2017) 52 Wake Forest Law Review 949. 
on these resources, such as manufacturers of fossil-fuelled cars. Indeed, the broad shift from unsustainable linear business models to the sustainable circular model ${ }^{48}$ involves financial risk for corporations not anticipating and adapting to this shift. The idea of technology change is insufficient to capture this risk - systems change is more appropriate.

Ultimately, the risk is existential: if we do not manage to reposition our economies and societies within planetary boundaries and in a way that secures a safe and just operating space for everybody now and in the future, we risk societal collapse. There are a number of scenarios that can lead to such collapse, including climate change and other environmental degradation, and social unrest caused by social inequality and the corporate undermining of the economic basis of our welfare systems. ${ }^{49}$

There is no form of social collapse which is likely to produce good, stable and long-term returns for investors. This final point underlines that that we cannot settle for a mainstream 'business case' approach. Recognising the financial risks of unsustainability does not mean that it is sufficient to only internalise environmental, social and broader governance issues to the extent that a clear cause-and-effect line can be drawn from ignoring an issue to the financial risk it entails for the corporation. Identifying the financial risk is not intended as a boundary of what issues are relevant to corporate sustainability. The point is to challenge the dichotomy of profits versus sustainability and show that, however little a corporate board may care about 'ethics' and 'corporate social responsibility', (un)sustainability will sooner or later, in one way or another, affect most corporations. Boards ignoring this are not doing their job.

\footnotetext{
${ }^{48}$ A linear business model is one that takes responsibility for, eg, a product, only until it is sold, and typically does not encompass the supply chain of the product and all its components. Conversely, a circular business model takes responsibility for a product from cradle to cradle, encompassing each stage from design to recycling/upcycling or management of the waste.

${ }^{49}$ The Sustainable Finance Initiative of the European Union is informed by the recognition of the necessity of ensuring that finance contribute to sustainability, and is potentially a promising development in this area. See further European Commission, Sustainable Finance (2018) $<$ https://ec.europa.eu/info/business-economy-euro/banking-and-finance/sustainablefinance_en>. See also Jay Cullen and Jukka Mähönen, 'Taming Unsustainable Finance: The Perils of Modern Risk Management' in Beate Sjåfjell and Christopher M Bruner (eds), Cambridge Handbook of Corporate Law, Corporate Governance and Sustainability (Cambridge University Press, forthcoming 2019) and the analysis in SMART Deliverable 2.4: Beate Sjåfjell et al (with contributions from the broader SMART team and its supporting network) Obstacles to Sustainable Global Business. Towards EU Policy Coherence for Sustainable Development $<$ https://www.smart.uio.no/publications/reports/>.
} 


\section{INTEgRATING SUSTAINABILITY INTO THE DUTIES OF THE CORPORATE BOARD}

Corporate boards have two alternatives. They can wake up to the financial risks of corporate unsustainability, and begin the process of internalising environmental, social and broader governance impacts of business in their decision-making, reshaping and redesigning business models to make them fit for purpose in the $21^{\text {st }}$ century. Or they can wait until the financial risks materialise, and, through experiencing the economic consequences, realise the inadequacy of 'business as usual'.

Corporate boards wishing to go with the first choice, and internalise sustainability concerns, will need guidance on how to do this. The social norm of shareholder primacy is so deeply entrenched that it has taken on the life of a legal myth, undermining corporate law. To overcome this myth, a reform of corporate law is called for. Society must take back the power of defining corporate purpose and the role and duties of the board, which has been captured by the social norm of shareholder primacy. Such a corporate law reform could be key to a broader reform, which may be necessary to mitigate the systemic unsustainability of business and finance today.

In previous work, a tentative proposal for such a reform of corporate law has been proposed. ${ }^{50}$ As a work-in-progress that is part of the ongoing research project 'Sustainable Market Actors for Responsible Trade' (SMART, 20162020 ), this proposal is being developed further in order to formulate an integrated 'Sustainable Governance Model'. The SMART Sustainable Governance Model is envisaged as a possible basis for corporate law reform and as guidance for individual businesses. It could also be implemented through a reform of corporate governance codes or sectorial guidelines. As an integrated part of the Sustainable Governance Model, a 'Sustainability Assessment Tool' is under development. ${ }^{51}$ The SMART Sustainability Assessment Tool is based on an assessment of a broad range of well-established assessment and

\footnotetext{
${ }^{50}$ This idea for a reform proposal was, in its first version, presented by the author together with Jukka Mähönen in the Nordic context, and thereafter, informed by inspiring discussions in the Sustainable Companies team, as a potential EU law proposal. See Beate Sjåfjell and Jukka Mähönen, 'Upgrading the Nordic Corporate Governance Model for Sustainable Companies' (2014) 11 European Company Law 58 and Beate Sjåfjell, 'Corporate Governance for Sustainability: The Necessary Reform of EU Company Law' in Sjåfjell and Wiesbrock, above n 33, 97.

${ }^{51}$ María Jesús Muñoz-Torres et al, 'An Assessment Tool to Integrate Sustainability Principles into the Global Supply Chain’ (2018) 10 Sustainability 535.
} 
certification schemes, showing that none of them is comprehensive and stringent enough to provide a reliable and full sustainability assessment. ${ }^{52}$

The proposed Sustainable Governance Model, which is addressed to the corporate board and management of business entities, involves the business conducting a sustainability framework analysis. The business would position itself within the life cycle of the products or services integral to its value creation, define its value chains, and develop a sustainability strategy. From this starting point, the Model outlines a research-based process of identifying the business's sustainability footprint, which would give the business a basis for meaningful sustainability reporting. The sustainability reporting would not be an end goal but a part of this proposed integral Sustainable Governance Model, as an element of a continuous process towards corporate sustainability.

The realisation of the enormous potential for sustainable value creation within each company cannot be undertaken through regulation in a command-andcontrol, top-down manner. Rather, each company must identify its own individual, innovative way of creating sustainable value. Arguably, a way to achieve this is to ensure that the board declares its commitment to sustainable governance, for example in the following terms:

The board commits itself to ensuring the creation of sustainable value within planetary boundaries. To this end, the board shall adopt and implement a sustainable governance model for the company, encompassing all of the company's areas of business and the full life impacts of its products, services and processes.

The adoption and implementation of a sustainable governance model should result in, where necessary, a reshaping of the company's business model through which the company will create sustainable value within planetary boundaries. Life-cycle thinking on the product and service level is also a key element. A full cradle-to-cradle approach to the goods and/or services that form the basis for the value creation of the company allows for a full overview of the environmental, social and economic consequences of the company's business. ${ }^{53}$ This overview would include every phase of the product's or

\footnotetext{
52 See SMART Deliverable 5.1: María Jesús Muñoz-Torres et al, Lifecycle Thinking: Issues to Be Considered (29 May 2017) <https://www.smart.uio.no/resources/reports/reports/d5.1.pdf $>$.

${ }^{53}$ This proposal fits well together with the integrated product policy of the EU where the lifecycle perspective is identified as the leading principle. This is also supported by the European Commission's renewed focus on life-cycle analysis, which we see through its Joint Research Centre's establishment of the European Platform on Life Cycle Assessment (EPLCA), and the identification of life cycle analysis as the 'best framework for assessing the potential environmental impacts of products'. See European Commission, Integrated Product Policy
} 
service's life cycle. For example, in the case of products, the overview would take in the sourcing of the materials used in the production, the production itself, the marketing and selling of the product, the user phase and, finally, the recycling or waste management of the product. For services, including financial services, similar life-cycle approaches should be carried out, encompassing the impacts of the components of the service and, for financial services, of the processes or products they finance.

Such a comprehensive life-cycle approach would be a way of dealing with the fragmentation of responsibility for environmental and social impacts that we see today through multinational groups of companies and global value chains. The approach could also be a way of implementing in practice the EU's NonFinancial Reporting Directive, in a manner that could realise its potential for change. ${ }^{54}$

\section{TOWARdS SUSTAINABLE Business?}

A reform along the lines suggested above may appear radical, and therefore unrealistic. However, we know that 'business as usual' is a very certain path towards a very uncertain future, and that we need to find new ways to work together to bring about the shift to sustainability. Academic engagement with business and finance may be one small contribution to mitigating the shareholder primacy norm. ${ }^{55}$

We also know that the social norm of shareholder primacy is only one barrier to sustainable business and finance, albeit a very significant one. A 2018 report from the SMART Project highlights a broader set of barriers preventing business and finance from realising their potential for sustainability. ${ }^{56}$ These include a lack of willingness to break away from entrenched economic beliefs, such as belief in the self-correcting ability of fully-informed markets, as well as the lack of relevant, reliable and verified information on the impact of transnational business and finance on sustainability. Also, even where positive developments can be identified, a lack of understanding of the planetary,

COM (2003) 302 final. Also Eléonore Maitre-Ekern, 'Towards an Integrated Product Regulatory Framework Based on Life-cycle Thinking' in Sjåfjell and Wiesbrock (eds), above n 33, 144.

${ }^{54}$ Above n 38. See further Beate Sjåfjell, 'Bridge over Troubled Water: Corporate Law Reform for Life-Cycle Based Governance and Reporting' (Research Paper No 2016-23, University of Oslo Faculty of Law, 22 November 2016) <https://ssrn.com/abstract=2874270>.

${ }^{55}$ SMART invites interested business and finance representatives to engage with us through our Creating Change platform $<$ https://www.smart.uio.no/creating-change/ $>$.

${ }^{56}$ Sjåfjell et al, above $n 46$. 
systemic and complex nature of sustainability renders true progress difficult. Climate change mitigation appears to be perceived as easier to quantify and thereby to concretise than other planetary boundaries, causing these other boundaries, as well as the social dimension of sustainability, to be ignored. A major conclusion to be drawn from this is that corporate law reform, integrating sustainability into the heart of decision-making in business, is a necessary part of a broader set of reforms. ${ }^{57}$

Recognising the financial risks of unsustainability may turn out to be the driver of such necessary reform. This reform may start on the legislative level, or may occur through bottom-up experimentation by individual businesses, this leading to the development of sectorial guidelines, reform of other voluntary schemes or systems, and finally to law reform.

The EU's Sustainable Finance Initiative has led to an opening up, for the first time, of a discussion at the EU level of the integration of sustainability into the duties of the corporate board. ${ }^{58}$ This may be an early indication that recognising the financial risk of unsustainability will indeed be a first step towards acceptance of the necessity of fundamental change, and increased willingness to work across sectors and beyond path-dependent silos to achieve this change. Certainly, in light of the convergence of crises we face, innovative and evidence-based initiatives are necessary. We do not have much time.

${ }^{57}$ Ibid.

${ }^{58}$ European Commission, Action Plan: Financing Sustainable Growth, COM (2018) 97 final. See also above $\mathrm{n} 499$. 